\title{
Modulation of $\mathrm{BK}_{\mathrm{Ca}}$ channel gating by endogenous signaling molecules
}

\author{
Shangwei Hou ${ }^{1}$, Stefan H. Heinemann ${ }^{2}$, and Toshinori Hoshi ${ }^{1}$ \\ 1 Department of Physiology, Richards D100, 3700 Hamilton Walk, University of Pennsylvania, \\ Philadelphia, PA 19104, USA \\ 2 Center for Molecular Biomedicine, Department of Biophysics, Friedrich Schiller University Jena, \\ Hans-Knöll-St. 2, D-07745 Jena, Germany
}

\section{Abstract}

Large-conductance $\mathrm{Ca}^{2+}$ - and voltage-activated $\mathrm{K}^{+}\left(\mathrm{BK}_{\mathrm{Ca}}\right.$, MaxiK or Slo1) channels are expressed in almost every tissue in our body and participate in many critical functions such as neuronal excitability, vascular tone regulation and neurotransmitter release. The functional versatility of $\mathrm{BK}_{\mathrm{Ca}}$ channels owes in part to the availability of a spectacularly wide array of biological modulators of the channel function. In this review, we focus on modulation of $\mathrm{BK}_{\mathrm{Ca}}$ channels by small endogenous molecules, emphasizing their molecular mechanisms. The mechanistic information available from studies on the small naturally occurring modulators is expected to contribute to our understanding of the physiological and pathophysiological roles of $\mathrm{BK}_{\mathrm{Ca}}$ channels.

\section{Introduction}

Large-conductance $\mathrm{Ca}^{2+}$ - and voltage-activated $\mathrm{K}^{+}\left(\mathrm{BK}_{\mathrm{Ca}}\right.$, MaxiK, $\left.\mathrm{K}_{\mathrm{Ca}} 1.1\right)$ channels are well known for their roles in regulation of membrane excitability partly owing to their large conductance, $250-300 \mathrm{pS}$ in symmetrical $150 \mathrm{mM} \mathrm{K}^{+}$, and to the synergic activation mechanism encompassing membrane depolarization and intracellular $\mathrm{Ca}^{2+} / \mathrm{Mg}^{2+}$ (98). The inter-dependent activation mechanism enables $\mathrm{BK}_{\mathrm{Ca}}$ channels to typically exert a negative feedback influence on cellular excitability $(98,118)$. The importance of $\mathrm{BK}_{\mathrm{Ca}}$ channels in regulation of vascular tone, determination of action potential duration and frequency, and neurotransmitter release, has been well documented (98). Consistent with the functional importance, notable phenotypes, such as hypertension, erectile dysfunction, and urinary incontinence, are associated with inhibition or down regulation of the $\mathrm{BK}_{\mathrm{Ca}}$ channel activity $(5,101)$. Conversely, enhancement or up regulation of the channel function in select cells may offer protection against some of the aforementioned disorders $(20,25,41,132)$.

Structurally, $\mathrm{BK}_{\mathrm{Ca}}$ channels are composed of four pore-forming Slo1 $(\alpha)$ subunits, each of which contains 7 transmembrane segments (S0-S6) and a large C-terminal cytoplasmic region (98). S1-S4 form the primary voltage-sensor domain (VSD), and S5, P and S6 together form the main ion permeation domain. The cytoplasmic area is postulated to harbor two homologous structural units termed "regulators of conductance for $\underline{\mathrm{K}}^{+ \text {" }}$ (RCK1 and RCK2) based on partial sequence similarity to the bacterial $\mathrm{K}^{+}$channel MthK whose highresolution structures are known (56,57). Four sets of RCK1/RCK2 dimers are envisioned to form a moving structure termed a "gating ring". Consistent with the gating ring hypothesis, $\mathrm{Ca}^{2+}$-dependent conformational changes in a recombinant Slo1 RCK2 protein have been detected (135). The detailed activation mechanism of the $\mathrm{BK}_{\mathrm{Ca}}$ channel is yet to be elucidated but the atomic structural information available from voltage-gated Kv1.2/2.1 channels $(73,74)$ and $\mathrm{Ca}^{2+}$-gated MthK channels $(56,57)$ forms a basis of the following 
model of $\mathrm{BK}_{\mathrm{Ca}}$ channel activation. The VSDs transduce changes in membrane potential and their movements are electromechanically coupled to the permeation gate within the pore domain. Extensive mutagenesis studies suggest that the activation by $\mathrm{Ca}^{2+}$ probably involves two distinct high-affinity $\mathrm{Ca}^{2+}$ sensors per subunit: the RCK1 sensor (130) and the $\mathrm{Ca}^{2+}$ bowl sensor (102). Activation of the $\mathrm{Ca}^{2+}$ sensors induces conformational changes in the gating ring and leads to opening of the permeation gate near/within S6 via the linkers connecting the gating ring and S6 $(78,88,130)$. The interactions among the gate, VSDs and divalent cation sensors, are allosteric and reciprocal (78). $\mathrm{Ca}^{2+}$ binding facilitates opening of the gate, and, conversely, opening of the gate facilitates binding of $\mathrm{Ca}^{2+}$ to its sensors by increasing the binding affinity. However, the coupling between the gate and the voltage/ intracellular ligand sensors is such that even without VSD activation and $\mathrm{Ca}^{2+}$, the gate may open once every few minutes on the average (47). Furthermore, open probability $\left(P_{\mathrm{o}}\right)$ of the channel approaches unity at sufficiently depolarized voltages without $\mathrm{Ca}^{2+}$, and the channel opens frequently at negative voltages without VSD activation with high concentrations of $\mathrm{Ca}^{2+}$.

Only one gene (KCNMA1) (23) codes for the pore-forming Slo1 subunit but the functional properties of the $\mathrm{BK}_{\mathrm{Ca}}$ channel are exceptionally diverse, encompassing many mechanisms, from transcriptional regulation (67), microRNA-mediated regulation (11), alternative splicing (1), to acute modulation of gating by signaling molecules. Alternative splicing of the RNA produces numerous transcripts, translating to diverse Slo1 proteins with distinct functional properties in different tissues and in different hormonal states $(105,115,131)$. To further increase the diversity, native $\mathrm{BK}_{\mathrm{Ca}}$ channel complexes often contain auxiliary $\beta$ subunits (KCNMB) in a tissue-specific manner (66). Four $\beta$ subunits, $\beta_{1}-\beta_{4}$ $(10,21,65,66,89,119)$, have been identified, each of which contains two transmembrane segments connected by a large extracellular loop, leaving both $\mathrm{N}$ and $\mathrm{C}$ termini in the intracellular side (89). Functionally, the presence of $\beta$ subunits markedly alters the channel's gating and pharmacological characteristics $(10,84,89,117)$. Recent evidence also shows that native $\mathrm{BK}_{\mathrm{Ca}}$ channels are part of macromolecular signaling complexes that include enzymes $(4,76,124)$ and/or ion channels $(13,37)$ to mediate local and spatially directed signaling. Once assembled, the $\mathrm{BK}_{\mathrm{Ca}}$ channel activity is subject to modulation by a wide spectrum of biologically relevant factors such as serine/threonine/tyrosine phosphorylation, cysteine/ methionine oxidation, steroid hormones, and gases (oxygen, nitric oxide (NO), and carbon monoxide (CO)) $(52,69,120,123,124)$. Of the modulatory factors, phosphorylation of $\mathrm{BK}_{\mathrm{Ca}}$ channels has been studied extensively and summarized (103). This review primarily focuses on examples of regulation of $\mathrm{BK}_{\mathrm{Ca}}$ channels by other molecules $-\mathrm{H}^{+}$, heme, $\mathrm{CO}$, reactive oxygen and nitrogen species, and lipids.

\section{Protons, $\mathrm{H}^{+}$}

$\mathrm{H}^{+}$is a vitally important ion and its intracellular concentration is under a tight control.

However, some fluctuations in $\mathrm{pH}_{\mathrm{i}}$ may occur as a consequence of normal cell function (26). Depolarization by action potentials and synaptic potentials may noticeably increase intracellular $\mathrm{H}^{+}$concentration $\left(\left[\mathrm{H}^{+}\right]_{\mathrm{i}}\right)(26)$. Additionally, a large fall in $\mathrm{pH}_{\mathrm{i}}$, as much as one unit, is possible under pathological conditions, such as cerebral ischemia (111). Not surprisingly, numerous types of ion channels are sensitive to intracellular $\mathrm{H}^{+}$; an increase in $\left[\mathrm{H}^{+}\right]_{\mathrm{i}}$ typically decreases ionic currents. The current inhibition is most frequently attributed to a rapid permeation-pore blocking action of $\mathrm{H}^{+}(108)$.

By contrast, $\mathrm{BK}_{\mathrm{Ca}}$ channels are robustly activated by intracellular $\mathrm{H}^{+}$, a characteristic shared only by a few others among the $\mathrm{K}^{+}$channel family (80). Early studies, often using native $\mathrm{BK}_{\mathrm{Ca}}$ channels, reported that intracellular $\mathrm{H}^{+}$decreased ionic currents through $\mathrm{BK}_{\mathrm{Ca}}$ channels (27). Recent studies utilizing heterologously expressed Slo1 channels as well as 
native $\mathrm{BK}_{\mathrm{Ca}}$ channels now show that $\mathrm{H}^{+}$stimulates opening of the channel $(8,44,51,92)$. It is uncertain what accounts for the seemingly contradictory results.

Intracellular $\mathrm{H}^{+}$increases ionic currents through $\mathrm{BK}_{\mathrm{Ca}}$ channels in the absence of $\mathrm{Ca}^{2+}$ without altering the single-channel current size $(i)(8,44,51,92)$. The increase in open probability $\left(P_{\mathrm{o}}\right)$ caused by $\mathrm{H}^{+}$is accompanied by a $40 \sim 50 \mathrm{mV}$ shift in the macroscopic conductance-voltage curve $(\mathrm{GV})$ to the negative direction with an $\mathrm{EC}_{50}$ value of $\mathrm{pH}_{\mathrm{i}} 6.5$ and a Hill coefficient of $>2$ such that the nearly full effect is observed between $\mathrm{pH}_{\mathrm{i}}=6.0$ and 7.2 (8), a physiologically feasible range. A mutagenesis study identified His365 and His394 (using NP 002238 numbering) in the RCK1 sensor domain, which is important in the $\mathrm{Ca}^{2+}$ dependent activation (130), as the necessary residues, with His365 and His394 accounting for $2 / 3$ and $1 / 3$ of the shift in GV, respectively. Mutation of His365/His394 to neutral Ala approximated the voltage dependence at $\mathrm{pH}_{\mathrm{i}} 7.2$ whereas that to positively-charged $\mathrm{Arg}$ produced a voltage dependence similar to that at $\mathrm{pH}_{\mathrm{i}} 6.2$. Combined with the finding that the stimulatory effect of $\mathrm{H}^{+}$diminishes with increasing ionic strength, it has been suggested that the protonated imidazole side chains of His 365 and His394 electrostatically interact with nearby electronegative elements. One of the electrostatic interaction partners appears to be Asp367, which is a critical component in high-affinity $\mathrm{Ca}^{2+}$ sensing (130). In summary, it is envisioned that intracellular $\mathrm{H}^{+}$protonates the side chains of His365 and His394 located within the high-affinity $\mathrm{Ca}^{2+}$-sensor site in the RCK1 domain and then the positively charged side chains interact with Asp367. This interaction in part mimics the action of $\mathrm{Ca}^{2+}$, expanding the gating ring and promoting opening of the gate.

The RCK1 sensor in Slo1 responds to both $\mathrm{Ca}^{2+}$ and $\mathrm{H}^{+}$. This multi-ligand nature of the RCK1 sensor with regards to $\mathrm{H}^{+}$and $\mathrm{Ca}^{2+}$ is probably physiologically significant as the intracellular concentrations of these two ions are also reciprocally regulated $(7,134)$. The $\mathrm{H}^{+}$ sensitivity of the $\mathrm{BK}_{\mathrm{Ca}}$ channel may also play an important role in pathophysiological conditions, such as in cerebral ischemia during which significant increases in both intracellular $\mathrm{H}^{+}$and $\mathrm{Ca}^{2+}$ concentrations are observed (71).

\section{Heme}

Like $\mathrm{H}^{+}$, heme is a fundamentally important molecule, typically as a stable protein prosthetic group. Emerging evidence suggests that free intracellular heme may function as a non-genomic signaling molecule, acutely modulating $\mathrm{BK}_{\mathrm{Ca}}$ channels $(50,114)$.

Bioinformatic inspection of the Slo1 primary sequence suggested that the sequence $\mathrm{CKACH}$ $(114,125)$ in the linker region between the cytoplasmic RCK1 and RCK2 segments might be capable of coordinating heme. Indeed, heme applied to the cytoplasmic side decreased $P_{\mathrm{o}}$ in cell-free membrane patches with a high affinity $\left(\mathrm{IC}_{50}=\sim 70 \mathrm{nM}\right)$ without altering $i(114)$. The modulatory effect of heme is independent of the redox status of iron center but substitution of the iron with other metals generally interferes with its modulatory ability. Mutations in the sequence CKACH disrupted the sensitivity of the channel to heme $(55,114,123)$, suggesting that the sequence may be part of the heme binding site. This idea was further corroborated by UV-vis/electron paramagnetic resonance (EPR) spectroscopic measurements (114) and thin-layer chromatography/mass spectroscopy assays (55) performed on a model peptide whose sequence corresponds to the putative heme binding segment. The detailed mechanism of the heme action was addressed by Horrigan et al. (48), who isolated the contribution of each allosteric gating component to the overall gating. The measurements all together showed that heme is a modulator, not a simple inhibitor, of the Slo1 channel function such that it increases $P_{o}$ at negative voltages and decreases $P_{o}$ at more positive voltages. Interaction of heme with the RCK1-RCK2 linker segment may expand the gating ring and impede the gating ring-VSD interaction that normally accompanies activation of the channel (48). 
While the molecular mechanism of the heme action of the $\mathrm{BK}_{\mathrm{Ca}}$ channel is relatively clear, its physiological significance is less certain. If heme is in fact a signaling molecule, a mechanism to activate the signaling cascade and a mechanism to terminate the signal should exist. One way to activate the heme signaling pathway may be influx of heme across the plasma membrane using heme transporters $(95,104)$. The heme signal can be terminated by the action of heme oxygenase (HMOX)(79), thus removing any direct influence of heme on $\mathrm{BK}_{\mathrm{Ca}}$ channels. HMOX, however, produces a number of heme degradation products, including $\mathrm{CO}$, a putative gaseous messenger, which may exert distinct effects on the channels.

\section{Carbon monoxide, $\mathrm{CO}$}

One of the well-known effects of CO is to relax blood vessels (70). CO, like another gaseous messenger NO, binds to the heme iron center in soluble guanylyl cyclase (sGC) and increases its activity, leading to an increased level of cGMP and of phosphorylation by cGMP-dependent protein kinase (PKG) (96). Experimental phosphorylation of PKGconsensus Ser residues in Slo1 located near the $\mathrm{Ca}^{2+}$ bowl sensor (87) and at the distal Cterminus (38) increases $P_{\mathrm{o}}$ by a few folds. The underlying mechanism of the PKG-mediated regulation is not yet known and neither is whether the aforementioned residues are dynamically phosphorylated in vivo in response to $\mathrm{CO}$.

In addition to the PKG-dependent mechanism, electrophysiological results suggest $\mathrm{CO}$ directly stimulates $\mathrm{BK}_{\mathrm{Ca}}$ channels, implicating that the channels themselves are gas sensors. $\mathrm{CO}$, applied as a gas or using CO-releasing molecules (CORMs) (58), increases $P_{\mathrm{o}}$ $(54,122,129)$ even in cell-free membrane patches $(120,123,124,126)$, suggestive of the possibility that $\mathrm{CO}$ modulates the channel directly or indirectly through those entities intimately associated with the channel proteins, possibly in the same macromolecular complex. Typically, CO-sensitive proteins, such as sGC, are heme proteins in which the reduced iron center $\left(\mathrm{Fe}^{2+}\right)$ interacts with $\mathrm{CO}(16)$. Thus, Jaggar et al. postulated that the heme bound to the $\mathrm{BK}_{\mathrm{Ca}}$ channel acts as a sensor for $\mathrm{CO}$; enhancement of the channel activity by $\mathrm{CO}$ reflects the ability of $\mathrm{CO}$ to remove the inhibitory influence of heme. However, this hypothesis is not consistent with more recent results. For example, $\mathrm{BK}_{\mathrm{Ca}}$ channels treated with the oxidant $\mathrm{H}_{2} \mathrm{O}_{2}$, which is expected to oxidize the heme iron and disrupt the CO-protein interaction (16), remain sensitive to $\mathrm{CO}$ (52). Furthermore, mutations that render the $\mathrm{BK}_{\mathrm{Ca}}$ channel insensitive to heme fails to disrupt the $\mathrm{CO}$ sensitivity $(52,123)$; the effects of heme and $\mathrm{CO}$ are mediated by different molecular loci. A recent study has shown that the RCK1 $\mathrm{Ca}^{2+}$ sensor in Slo1 is required for the stimulatory action of $\mathrm{CO}$ (52); mutation of His365, His394 or Asp367, the residues in the RCK1 sensor involved in the $\mathrm{H}^{+}$ and $\mathrm{Ca}^{2+}$ sensitivity, also eliminates the $\mathrm{CO}$ sensitivity (52). This finding suggests that both $\mathrm{CO}$ and $\mathrm{H}^{+}$increase $P_{\mathrm{o}}$ by mimicking the action of $\mathrm{Ca}^{2+}$ on the RCK1 sensor (52). The essential roles of His365 and His394 in the CO sensitivity are consistent with the earlier observations that low $\mathrm{pH}_{\mathrm{i}}$ and the histidine modifier DEPC antagonize the $\mathrm{CO}$ action $(52,120)$.

The results summarized above collectively show that the RCK1 sensor encompassing His365, His394 and Asp367 is essential for the high sensitivity of the $\mathrm{BK}_{\mathrm{Ca}}$ channel to multiple ligands: $\mathrm{Ca}^{2+}, \mathrm{H}^{+}$and $\mathrm{CO}$. This finding has been interpreted to indicate that the RCK1 sensor is multi-ligand in nature and accommodates $\mathrm{Ca}^{2+}, \mathrm{H}^{+}$or $\mathrm{CO}(51,52)$. Alternatively, it may be postulated that a separate sensor for each ligand exists and that the binding information converges on the aforementioned His and Asp residues and transmitted to the channel's gate. Several lines of results, including that the effects of mutations affecting the $\mathrm{Ca}^{2+} / \mathrm{H}^{+}$sensitivity are generally additive $(51,94)$, favor the former multiligand postulate. 
The physicochemical mechanism by which CO interacts with the RCK1 sensor remains elusive. It is conventionally believed that $\mathrm{CO}$-sensing proteins requires a metal or heme cofactor (16). The available structures of the bacterial channel MthK, which shows a reasonable degree of primary sequence similarity to the $\mathrm{BK}_{\mathrm{Ca}}$ channel, do not suggest that the Slo1 RCK1 sensor harbors any metal or heme cofactor $(56,57)$. As an alternative idea, an electrostatic interaction between the weak dipole moment of CO and the RCK1 ligand sensor pocket comprised of His365, His394, and Asp367 has been suggested to contribute (52). In addition to the RCK sensor, an additional CO interaction site may exist in the Slo1 channel (123). CO may increase $P_{\mathrm{o}}$ even at saturating concentrations of $\mathrm{Ca}^{2+}(123)$, which cannot be easily explained by the effect of $\mathrm{CO}$ as a $\mathrm{Ca}^{2+}$ mimetic for the RCK1 sensor (52).

In many cell types, hypoxia inhibits $\mathrm{BK}_{\mathrm{Ca}}$ channels and the direct stimulation of the $\mathrm{BK}_{\mathrm{Ca}}$ channel by $\mathrm{CO}$ represents one of the cellular mechanisms of oxygen sensing (124). In oxygen-sensing carotid body glomus cells, Slo1 proteins are found closely associated with HMOX2 (124), which catalyzes heme to produce $\mathrm{CO}$ in an $\mathrm{O}_{2}$-dependent manner (61). It has been postulated that under normoxia, $\mathrm{CO}$ generated by HMOX2 continuously stimulates the $\mathrm{BK}_{\mathrm{Ca}}$ channel and that hypoxia inhibits HMOX2 and removes the stimulatory influence of $\mathrm{CO}$ on the $\mathrm{BK}_{\mathrm{Ca}}$ channel (124). The overall scheme is supported by several lines of evidence, including the results of HMOX2 gene-knockdown experiments (124). However, the HMOX2-mediated oxygen sensing mechanism may not the dominant one in vivo because mice with the HMOX2 gene constitutively disrupted show relatively normal hypoxic responses $(82,90)$.

\section{Reactive oxygen/nitrogen species (ROS/RNS)}

The aerobic existence inevitably creates reactive molecules capable of oxidizing cellular constituents including proteins (45). While excess concentrations of the reactive molecules are clearly deleterious, causing oxidative stress, cells utilize some of the reactive molecules at low concentrations as vital signaling molecules (53).

Redox modulation of cell function has been difficult to study in part because the experimental tools available to manipulate the levels of reactive species often lack desired specificity and because reactive species are capable of readily modifying multiple aminoacid residues, including cysteine, methionine, histidine, tryptophan, and tyrosine. Furthermore, some oxidation reactions are critically dependent on multivalent cations, such as $\mathrm{Fe}^{2+} / \mathrm{Fe}^{3+}$, which may be present as contaminating species. It is not surprising then that treatment of cells/membrane patches containing $\mathrm{BK}_{\mathrm{Ca}}$ channels with reactive species such as $\mathrm{H}_{2} \mathrm{O}_{2}$ has been reported to produce a myriad of effects $(9,19,24,68,121,128,136)$. A consensus effect of $\mathrm{H}_{2} \mathrm{O}_{2}$, a physiological oxidant produced during normal oxygen metabolism, applied to heterologously-expressed $\mathrm{BK}_{\mathrm{Ca}}$ channels is inhibitory, attributed largely to a decrease in $P_{\mathrm{O}}(19,33,77,106,112,113)$ and, to a lesser extent, a decrease in the number of channels available to open $(N)(106,137)$. Typically, the diminished $P_{\mathrm{o}}$ by $\mathrm{H}_{2} \mathrm{O}_{2}$ persists after wash, indicative of amino-acid modification, but the gating change is reversed by reducing agents such as the physiological reducing agent glutathione (GSH) $(19,33)$ as well as DTT $(33,77,106,113)$, all of which are capable of regenerating a free sulfhydryl group (-SH) in cysteine from the oxidized side chain sulfenic acid (-SOH). A variety of thiol modifying agents, such as NEM, DTNB and MTSEA $(33,113,121)$, also decrease $P_{\mathrm{o}}$, thus implicating that the absence of free sulfhydryl groups in $\mathrm{BK}_{\mathrm{Ca}}$ channel is critical. A systematic Cys-to-Ala mutagenesis of Slo1 showed that oxidation of Cys911 near the $\mathrm{Ca}^{2+}$ bowl sensor in the distal C-terminus decreased the energetic contribution of the $\mathrm{Ca}^{2+}$ bowl sensor to the channel activation (113). The proximity of Cys911 to the $\mathrm{Ca}^{2+}$ bowl sensor is in line with the $\mathrm{Ca}^{2+}$ dependence of the inhibitory effect; in the absence of $\mathrm{Ca}^{2+}$, the redox status of Cys911 plays little role but the effect becomes greater with increasing 
concentrations of $\mathrm{Ca}^{2+}$ while leaving that $\mathrm{Ca}^{2+}$ dependence mediated by the RCK1 sensor intact (113). In addition to Cys911 at the distal C-terminus, Cys430 in the RCK1 domain also contributes to the oxidation sensitivity of the $\mathrm{Ca}^{2+}$ dependence of the $\mathrm{BK}_{\mathrm{Ca}}$ channel (137). Both Cys430 and Cys911 are susceptible to air oxidation and account for the rundown phenomenon following patch excision (137). Additional Cys residues, whose oxidation alters the channel gating, are also present in the channel. One interesting example is the biologically modulated inclusion of the STREX exon in the cytoplasmic region of Slo1 (131). The STREX inclusion introduces additional Cys residues and potentiates the inhibitory effect of oxidation (36).

Reactive molecules other than $\mathrm{H}_{2} \mathrm{O}_{2}$ have been reported to affect $\mathrm{BK}_{\mathrm{Ca}}$ channels: $\mathrm{O}_{2}{ }^{\cdot-}$ $(72,113)$, $\mathrm{NO}(2,18,19,69)$, and peroxynitrite $\left(\mathrm{ONOO}^{-}\right)(72,77,113)$. Many of the effects are inhibitory in nature and some of the inhibitory effects are mediated by Cys911 (77,113). In addition, nitrothiosylation (for review, see (81)) of yet an unidentified cysteine residue induced by NO-releasing compounds may increase the channel activity $(2,18,69)$. It may be noted that application of a NO-releasing compound to heterologously-expressed $\mathrm{BK}_{\mathrm{Ca}}$ channels failed to increase $P_{\mathrm{o}}(52)$.

Direct biochemical/proteomic evidence that any of the Cys residues in the $\mathrm{BK}_{\mathrm{Ca}}$ channels are dynamically oxidized and reduced under physiological conditions is not yet available. Pathophysiologically, Cys oxidation in the $\mathrm{BK}_{\mathrm{Ca}}$ channel is likely to be a contributing factor in those disease states where oxidative stress is implicated. One such condition is diabetesinduced vascular dysfunction where oxidative stress is an important contributing factor and suggested to induce oxidation of Cys911, leading to impaired vasorelaxation (77).

Methionine is another amino acid readily susceptible to oxidation. Oxidation of methionine to methionine sulfoxide by the addition of an oxygen atom to its reactive sulfur atom changes its flexible and nonpolar side chain to a rigid and polar one, roughly equivalent to the side chain of lysine (15). Methionine oxidation has marked functional effects in many proteins including calmodulin (14), calcium/calmodulin-dependent kinase (35), and ion channels $(28,49,60)$ and is implicated in many phenomena including aging and neurodegenerative diseases $(49,107)$. In $\mathrm{BK}_{\mathrm{Ca}}$ channels, oxidation of any of one of the three Met residues M536, M712 and M739 located in the RCK1 and RCK2 domains by chloramines increases $P_{\mathrm{o}}$ in the absence of $\mathrm{Ca}^{2+}$ in part by shifting $\mathrm{GV}$ to the negative direction by $\sim 50 \mathrm{mV}$ (100). The overall shift in the voltage dependence is caused by stabilization of the activated state of VSD and of the open state of the gate (100).

Interestingly, the stimulatory effect of methionine oxidation in Slo1 is drastically potentiated by coexpression of the auxiliary subunit $\beta 1$ (99) but a mechanistic interpretation of the finding remains to be developed.

\section{Lipids and metabolites}

Lipids are a structurally diverse group of molecules that include fatty acids, phospholipids and steroids, and many lipids and lipid-related metabolites are recognized as cellular signaling molecules involved in regulation of a variety of physiological and pathophysiological processes including gating of $\mathrm{BK}_{\mathrm{Ca}}$ channels (17). The interest in modulation of $\mathrm{BK}_{\mathrm{Ca}}$ channels by lipids is further stimulated by the recent finding that voltage-dependent gating of ion channels critically depends on membrane phospholipids (133).

\section{Fatty acids: arachidonic acid and its metabolites}

Arachidonic acid, a fatty acid, initially synthesized from dietary sources in select cells, is stored in cell membranes and released to the cytoplasm by the action of phospholipases. 
Once released, arachidonic acid as well as its metabolites such as hydroxyeicosatetraenoic acids (HETEs), epoxyeicosatrienoic acid (EET), dihydroxyeicosatrienoic acids (DHETs), exert a variety of effects $(93,97)$, including stimulation of $\mathrm{BK}_{\mathrm{Ca}}$ channels in pituitary tumor cells $(32,127)$, artery smooth muscle cells $(3,6,29,46,63)$, and heterologous expression systems $(39,42)$. The stimulatory action of various fatty acids on the $\mathrm{BK}_{\mathrm{Ca}}$ channels has been typically attributed to an increase in $P_{\mathrm{O}}(3,29,32)$ and/or to an increase in $N(3)$. How the changes in $P_{\mathrm{o}}$ correlate with the changes in the functional domains of the channel, the gate, the VSDs and the gating ring, have not been fully explored.

Despite the large number of fatty acids capable of enhancing the $\mathrm{BK}_{\mathrm{Ca}}$ channel activity, considerable structural specificity has been reported, suggesting that the fatty acid effector, presumably the channel itself, has specific interaction sites. To effectively increase $P_{\mathrm{o}}$, fatty acids should have a cis conformation (32), a relatively long tail group $(\mathrm{C}>8)$ and a negatively charged head group (29). For example, oleic acid (C18), arachidonic acid (C20), and eicosapentaenoic acid (C20) meet these structural requirements and increase $\mathrm{BK}_{\mathrm{Ca}} P_{\mathrm{O}}$ by several folds $(29,32)$. The location of the double bonds in fatty acids may be also important $(39,127)$.

The biophysical mechanism and the molecular components necessary for the stimulatory action of the fatty acids are not yet clear. Because fatty acids may "flip" across cell membranes (59), it has been difficult to determine whether the fatty acid interaction sites face the intracellular side or extracellular side. Additionally, there is no clear consensus whether the auxiliary subunits of the $\mathrm{BK}_{\mathrm{Ca}}$ channel, $\beta 1-4$, are required for the fatty acid action. The predominantly vascular auxiliary subunit $\beta 1$ may not be required for 17,18 epoxyeicosatetraenoic acid, one metabolite of arachidonic acid, to activate the $\mathrm{BK}_{\mathrm{Ca}}$ channel, suggesting that the pore-forming Slo1 subunit is sufficient (46). In contrast, arachidonic acid increases $P_{\mathrm{o}}$ when Slo1 is expressed with $\beta 2$ or $\beta 3$ but not when expressed alone or coexpressed with $\beta 4$ (110). One likely but complicating possibility is that fatty acids differ in their $\beta$ subunit requirement.

\section{Phospholipids}

Phospholipids are an important constituent of cell membranes and have been known to alter the functions of $\mathrm{BK}_{\mathrm{Ca}}$ channels in many ways $(40,85,91)$. Phosphatidylinositol 4, 5-

bisphosphate $\left(\mathrm{PIP}_{2}\right)$ in particular has been a subject of intense investigation because this negatively charged phospholipid influences numerous ion channels and because it serves as a precursor for inositol 1, 4, 5-triphosophate $\left(\mathrm{IP}_{3}\right)$ and diacylglycerol (DAG), both of which in turn modulate many ion channels. This multifunctional nature of $\mathrm{PIP}_{2}$ is physiologically noteworthy but has hindered execution of well-controlled experiments (109). Nevertheless, an emerging paradigm is that $\mathrm{PIP}_{2}$, especially when phosphorylated by lipid kinases, directly affects many ion channels (109), and $\mathrm{BK}_{\mathrm{Ca}}$ channels appear to be no exception. This is illustrated in a recent study by Vaithianathan et al. (116), which showed that application of exogenous $\mathrm{PIP}_{2}$ to the cytoplasmic side at a physiological concentration $(\sim 10 \mu \mathrm{M})(83)$ increases currents through both native vascular and heterologously-expressed $\mathrm{BK}_{\mathrm{Ca}}$ channels. The current enhancing effect of $\mathrm{PIP}_{2}$ depends on its negative phosphate group and the inositol moiety, and the washout kinetics is influenced by the acyl chain length. The importance of the negative phosphate group in $\mathrm{PIP}_{2}$ prompted Vaithianathan et al. to mutate a cluster of three positively-charged residues (RKK) in the Slo1 S6-RCK1 linker segment. Neutralization of the charged residues noticeably diminished the overall effect of $\mathrm{PIP}_{2}$, perhaps suggesting that the sequence RKK is a $\mathrm{PIP}_{2}$ interaction site. The involvement of the S6-RCK1 linker in the $\mathrm{PIP}_{2}$ action is reminiscent of the results obtained in KCNQ, another voltage-gated $\mathrm{K}^{+}$channel (138). Biophysically, $\mathrm{PIP}_{2}$ increases $P_{\mathrm{O}}$ in the $\mathrm{BK}_{\mathrm{Ca}}$ channel by shifting GV to the negative direction by $\sim 15 \mathrm{mV}$ at an intermediate concentration of $\mathrm{Ca}^{2+}$. It is interesting to note that a similar shift in the voltage dependence is observed when the S6- 
RCK1 linker is shortened (88); binding of PIP $_{2}$ to the linker region may affect the coupling process between the gate in the pore module and the cytoplasmic gating structure.

\section{Steroid hormones}

Steroid hormones are well known for their genomic effects but their acute, non-genomic mode of action involving direct binding to membrane-bound effectors, including $\mathrm{BK}_{\mathrm{Ca}}$ channels, is starting to be appreciated (86). Multiple steroid hormones, including estrogen (117), testosterone (43), and dehydroepiandrosterone (62), glucocorticoids (75), have been reported to acutely affect $\mathrm{BK}_{\mathrm{Ca}}$ channels. Because estrogen may offer a cardioprotective effect (30), the non-genomic action of estrogen on $\mathrm{BK}_{\mathrm{Ca}}$ channels has been extensively investigated. Acute application of estradiol (17 $\beta$-estradiol) relaxes vascular smooth muscle in a low $\mu \mathrm{M}$ range (64) and activates native vascular $\mathrm{BK}_{\mathrm{Ca}}$ channels and heterologouslyexpressed Slo1- $\beta 1$ channels with an $\mathrm{EC}_{50}$ of a few $\mu \mathrm{M}$ in a $\mathrm{Ca}^{2+}$-dependent manner with the current enhancing effect diminishing at higher concentrations of $\mathrm{Ca}^{2+}(31,62,117)$. Importantly, clear structural specificity exists because $17 \alpha$-estradiol is less effective than $17 \beta$-estradiol (117). The pore-forming subunit Slo1 is not sufficient for the $17 \beta$-estradiol sensitivity but the robust $17 \beta$-estradiol sensitivity requires coexpression of a $\beta$ subunit, either $\beta 1, \beta 2$ or $\beta 4(10,62,117)$. The observation that a membrane impermeant analog of $17 \beta$-estradiol applied from the extracellular side activates the $\mathrm{BK}_{\mathrm{Ca}}$ channel suggests that the estradiol interaction site may lie near the extracellular side of the Slo1- $\beta$ complex (117), distinct from the PIP 2 interaction site located near the cytoplasmic side of S6 (116).

At low concentrations of $\mathrm{Ca}^{2+}, 17 \beta$-estradiol shifts $\mathrm{GV}$ to the negative direction without altering $i(31,62,117)$. In the presence of $17 \beta$-estradiol, marked changes in the singlechannel kinetics, such as an increase in the mean burst duration have been noted (31). However, how the gating changes by $17 \beta$-estradiol can be accounted for by the prevailing allosteric gating scheme (47) is unclear. In addition, a $\beta$ subunit-independent inhibitory effect of estrogen mediated by the Slo1 pore probably exists (34). Other steroids such as corticosterone (62,75), dehydroepiandrosterone (62) and lithocholate (22) also activate $\mathrm{BK}_{\mathrm{Ca}}$ channels in a $\beta$ subunit-dependent manner.

\section{Concluding remarks}

Acute modulation of $\mathrm{BK}_{\mathrm{Ca}}$ channels greatly expands their functional repertories, allowing the channels to contribute to multitudes of physiological and pathophysiological phenomena. Important mechanistic insights into the channel regulation by small molecules such as $\mathrm{Ca}^{2+}$, $\mathrm{Mg}^{2+}$ and $\mathrm{H}^{+}$are now available and the mechanisms of action of other modulatory agents on the $\mathrm{BK}_{\mathrm{Ca}}$ channel gating should become better elucidated in the near future. The $\mathrm{BK}_{\mathrm{Ca}}$ channel gating is allosterically mediated by three major domains of the channel, the pore, VSDs and the gating ring, all of which undergo rapid and marked conformational changes, and any modifications of the energetics and/kinetics of the functional domains could change the channel current size. Thus, additional modulatory phenomena of $\mathrm{BK}_{\mathrm{Ca}}$ channels are certainly waiting to be discovered. Such future studies will incorporate the realization that $\mathrm{BK}_{\mathrm{Ca}}$ channels form macromolecular complexes with other signaling molecules, such as voltage-dependent $\mathrm{Ca}^{2+}$ channels $(12,13)$, HMOX2 (124) and protein kinases/phosphatases (76). The macromolecular assembly formation itself may be dynamic and subject to modulation. The knowledge obtained from studies of the modulator action could contribute to rational design of therapeutically useful low-molecular-weight compounds targeting $\mathrm{BK}_{\mathrm{Ca}}$ channels. Dysfunction of a modulatory pathway may underlie a disease state and synthetic compounds could be designed to regulate the pathway in a predictable manner. Much work and excitement lie ahead. 


\section{Acknowledgments}

The authors thank Dr. F. Horrigan for discussion. The authors' laboratories are supported by NIH and SFB 604 (TP A4).

\section{References}

1. Adelman JP, Shen KZ, Kavanaugh MP, Warren RA, Wu YN, Lagrutta A, Bond CT, North RA. Calcium-activated potassium channels expressed from cloned complementary DNAs. Neuron 1992;9:209-216. [PubMed: 1497890]

2. Ahern GP, Hsu SF, Jackson MB. Direct actions of nitric oxide on rat neurohypophysial $\mathrm{K}^{+}$ channels. J Physiol 1999;520:165-176. [PubMed: 10517809]

3. Ahn DS, Kim YB, Lee YH, Kang BS, Kang DH. Fatty acids directly increase the activity of $\mathrm{Ca}^{2+}$ activated $\mathrm{K}^{+}$channels in rabbit coronary smooth muscle cells. Yonsei Med J 1994;35:10-24. [PubMed: 8009892]

4. Alioua A, Mahajan A, Nishimaru K, Zarei MM, Stefani E, Toro L. Coupling of c-Src to large conductance voltage- and $\mathrm{Ca}^{2+}$-activated $\mathrm{K}^{+}$channels as a new mechanism of agonist-induced vasoconstriction. Proc Natl Acad Sci U S A 2002;99:14560-14565. [PubMed: 12391293]

5. Amberg GC, Bonev AD, Rossow CF, Nelson MT, Santana LF. Modulation of the molecular composition of large conductance, $\mathrm{Ca}^{2+}$ activated $\mathrm{K}^{+}$channels in vascular smooth muscle during hypertension. J Clin Invest 2003;112:717-724. [PubMed: 12952920]

6. Archer SL, Gragasin FS, Wu X, Wang S, McMurtry S, Kim DH, Platonov M, Koshal A, Hashimoto K, Campbell WB, Falck JR, Michelakis ED. Endothelium-derived hyperpolarizing factor in human internal mammary artery is 11,12-epoxyeicosatrienoic acid and causes relaxation by activating smooth muscle $\mathrm{BK}_{\mathrm{Ca}}$ channels. Circulation 2003;107:769-776. [PubMed: 12578883]

7. Austin $\mathrm{C}$, Wray S. Interactions between $\mathrm{Ca}^{2+}$ and $\mathrm{H}^{+}$and functional consequences in vascular smooth muscle. Circ Res 2000;86:355-363. [PubMed: 10679489]

8. Avdonin V, Tang XD, Hoshi T. Stimulatory action of internal protons on Slo1 BK channels. Biophys J 2003;84:2969-2980. [PubMed: 12719228]

9. Barlow RS, White RE. Hydrogen peroxide relaxes porcine coronary arteries by stimulating $\mathrm{BK}_{\mathrm{Ca}}$ channel activity. Am J Physiol 1998;275:H1283-1289. [PubMed: 9746477]

10. Behrens R, Nolting A, Reimann F, Schwarz M, Waldschutz R, Pongs O. hKCNMB3 and hKCNMB4, cloning and characterization of two members of the large-conductance calciumactivated potassium channel $\beta$ subunit family. FEBS Lett 2000;474:99-106. [PubMed: 10828459]

11. Bell TJ, Miyashiro KY, Sul JY, McCullough R, Buckley PT, Jochems J, Meaney DF, Haydon P, Cantor C, Parsons TD, Eberwine J. Cytoplasmic $\mathrm{BK}_{\mathrm{Ca}}$ channel intron-containing mRNAs contribute to the intrinsic excitability of hippocampal neurons. Proc Natl Acad Sci U S A 2008;105:1901-1906. [PubMed: 18250327]

12. Berkefeld H, Fakler B. Repolarizing responses of $\mathrm{BK}_{\mathrm{Ca}}-\mathrm{Cav}$ complexes are distinctly shaped by their Cav subunits. J Neurosci 2008;28:8238-8245. [PubMed: 18701686]

13. Berkefeld H, Sailer CA, Bildl W, Rohde V, Thumfart JO, Eble S, Klugbauer N, Reisinger E,

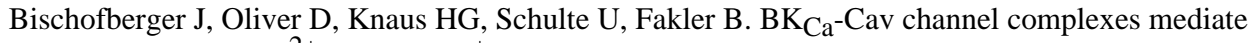
rapid and localized $\mathrm{Ca}^{2+}$-activated $\mathrm{K}^{+}$signaling. Science 2006;314:615-620. [PubMed: 17068255]

14. Bigelow DJ, Squier TC. Redox modulation of cellular signaling and metabolism through reversible oxidation of methionine sensors in calcium regulatory proteins. Biochim Biophys Acta 2005; 1703:121-134. [PubMed: 15680220]

15. Black SD, Mould DR. Development of hydrophobicity parameters to analyze proteins which bear post- or cotranslational modifications. Anal Biochem 1991;193:72-82. [PubMed: 2042744]

16. Boczkowski J, Poderoso JJ, Motterlini R. CO-metal interaction: Vital signaling from a lethal gas. Trends Biochem Sci 2006;31:614-621. [PubMed: 16996273]

17. Boland LM, Drzewiecki MM. Polyunsaturated fatty acid modulation of voltage-gated ion channels. Cell Biochem Biophys 2008;52:59-84. [PubMed: 18830821] 
18. Bolotina VM, Najibi S, Palacino JJ, Pagano PJ, Cohen RA. Nitric oxide directly activates calciumdependent potassium channels in vascular smooth muscle. Nature 1994;368:850-853. [PubMed: 7512692]

19. Brakemeier S, Eichler I, Knorr A, Fassheber T, Kohler R, Hoyer J. Modulation of $\mathrm{Ca}^{2+}$-activated $\mathrm{K}^{+}$channel in renal artery endothelium in situ by nitric oxide and reactive oxygen species. Kidney Int 2003;64:199-207. [PubMed: 12787410]

20. Brenner R, Chen QH, Vilaythong A, Toney GM, Noebels JL, Aldrich RW. BK channel $\beta 4$ subunit reduces dentate gyrus excitability and protects against temporal lobe seizures. Nat Neurosci 2005;8:1752-1759. [PubMed: 16261134]

21. Brenner R, Jegla TJ, Wickenden A, Liu Y, Aldrich RW. Cloning and functional characterization of novel large conductance calcium-activated potassium channel $\beta$ subunits, hKCNMB3 and hKCNMB4. J Biol Chem 2000;275:6453-6461. [PubMed: 10692449]

22. Bukiya AN, Liu J, Toro L, Dopico AM. $\beta 1$ (KCNMB1) subunits mediate lithocholate activation of large-conductance $\mathrm{Ca}^{2+}$-activated $\mathrm{K}^{+}$channels and dilation in small, resistance-size arteries. Mol Pharmacol 2007;72:359-369. [PubMed: 17468198]

23. Butler A, Tsunoda S, McCobb DP, Wei A, Salkoff L. mSlo, a complex mouse gene encoding “maxi” calcium-activated potassium channels. Science 1993;261:221-224. [PubMed: 7687074]

24. Bychkov R, Pieper K, Ried C, Milosheva M, Bychkov E, Luft FC, Haller H. Hydrogen peroxide, potassium currents, and membrane potential in human endothelial cells. Circulation 1999;99:1719-1725. [PubMed: 10190882]

25. Cheney JA, Weisser JD, Bareyre FM, Laurer HL, Saatman KE, Raghupathi R, Gribkoff V, Starrett JE Jr, McIntosh TK. The maxi-K channel opener BMS-204352 attenuates regional cerebral edema and neurologic motor impairment after experimental brain injury. J Cereb Blood Flow Metab 2001;21:396-403. [PubMed: 11323525]

26. Chesler M. Regulation and modulation of $\mathrm{pH}$ in the brain. Physiol Rev 2003;83:1183-1221. [PubMed: 14506304]

27. Church J, Baxter KA, McLarnon JG. pH modulation of $\mathrm{Ca}^{2+}$ responses and a $\mathrm{Ca}^{2+}$-dependent $\mathrm{K}^{+}$ channel in cultured rat hippocampal neurones. J Physiol 1998;511:119-132. [PubMed: 9679168]

28. Ciorba MA, Heinemann SH, Weissbach H, Brot N, Hoshi T. Modulation of potassium channel function by methionine oxidation and reduction. Proc Natl Acad Sci U S A 1997;94:9932-9937. [PubMed: 9275229]

29. Clarke AL, Petrou S, Walsh JV Jr, Singer JJ. Modulation of $\mathrm{BK}_{\mathrm{Ca}}$ channel activity by fatty acids: structural requirements and mechanism of action. Am J Physiol Cell Physiol 2002;283:C14411453. [PubMed: 12372805]

30. Collins P, Rosano GM, Jiang C, Lindsay D, Sarrel PM, Poole-Wilson PA. Cardiovascular protection by oestrogen--a calcium antagonist effect? Lancet 1993;341:1264-1265. [PubMed: 8098404]

31. De Wet H, Allen M, Holmes C, Stobbart M, Lippiat JD, Callaghan R. Modulation of the BK channel by estrogens: examination at single channel level. Mol Membr Biol 2006;23:420-429. [PubMed: 17060159]

32. Denson DD, Wang X, Worrell RT, Eaton DC. Effects of fatty acids on BK channels in $\mathrm{GH}_{3}$ cells. Am J Physiol Cell Physiol 2000;279:C1211-1219. [PubMed: 11003601]

33. DiChiara TJ, Reinhart PH. Redox modulation of hslo $\mathrm{Ca}^{2+}$-activated $\mathrm{K}^{+}$channels. J Neurosci 1997;17:4942-4955. [PubMed: 9185532]

34. Dick GM, Sanders KM. (Xeno)estrogen sensitivity of smooth muscle BK channels conferred by the regulatory $\beta 1$ subunit: a study of beta1 knockout mice. J Biol Chem 2001;276:44835-44840. [PubMed: 11590153]

35. Erickson JR, Joiner ML, Guan X, Kutschke W, Yang J, Oddis CV, Bartlett RK, Lowe JS, O’Donnell SE, Aykin-Burns N, Zimmerman MC, Zimmerman K, Ham AJ, Weiss RM, Spitz DR, Shea MA, Colbran RJ, Mohler PJ, Anderson ME. A dynamic pathway for calcium-independent activation of CaMKII by methionine oxidation. Cell 2008;133:462-474. [PubMed: 18455987]

36. Erxleben C, Everhart AL, Romeo C, Florance H, Bauer MB, Alcorta DA, Rossie S, Shipston MJ, Armstrong DL. Interacting effects of $\mathrm{N}$-terminal variation and strex exon splicing on slo potassium 
channel regulation by calcium, phosphorylation, and oxidation. J Biol Chem 2002;277:2704527052. [PubMed: 12016222]

37. Fakler B, Adelman JP. Control of $\mathrm{K}_{\mathrm{Ca}}$ channels by calcium nano/microdomains. Neuron 2008;59:873-881. [PubMed: 18817728]

38. Fukao M, Mason HS, Britton FC, Kenyon JL, Horowitz B, Keef KD. Cyclic GMP-dependent protein kinase activates cloned $\mathrm{BK}_{\mathrm{Ca}}$ channels expressed in mammalian cells by direct phosphorylation at serine 1072. J Biol Chem 1999;274:10927-10935. [PubMed: 10196172]

39. Fukao M, Mason HS, Kenyon JL, Horowitz B, Keef KD. Regulation of $\mathrm{BK}_{\mathrm{Ca}}$ channels expressed in human embryonic kidney 293 cells by epoxyeicosatrienoic acid. Mol Pharmacol 2001;59:1623. [PubMed: 11125019]

40. Green WN, Andersen OS. Surface charges and ion channel function. Annu Rev Physiol 1991;53:341-359. [PubMed: 1710438]

41. Gribkoff VK, Starrett JE Jr, Dworetzky SI, Hewawasam P, Boissard CG, Cook DA, Frantz SW, Heman K, Hibbard JR, Huston K, Johnson G, Krishnan BS, Kinney GG, Lombardo LA, Meanwell NA, Molinoff PB, Myers RA, Moon SL, Ortiz A, Pajor L, Pieschl RL, Post-Munson DJ, Signor LJ, Srinivas N, Taber MT, Thalody G, Trojnacki JT, Wiener H, Yeleswaram K, Yeola SW. Targeting acute ischemic stroke with a calcium-sensitive opener of maxi-K potassium channels. Nat Med 2001;7:471-477. [PubMed: 11283675]

42. Gu XQ, Siemen D, Parvez S, Cheng Y, Xue J, Zhou D, Sun X, Jonas EA, Haddad GG. Hypoxia increases BK channel activity in the inner mitochondrial membrane. Biochem Biophys Res Commun 2007;358:311-316. [PubMed: 17481584]

43. Han DH, Chae MR, Jung JH, So I, Park JK, Lee SW. Effect of testosterone on potassium channel opening in human corporal smooth muscle cells. J Sex Med 2008;5:822-832. [PubMed: 18208499]

44. Hayabuchi Y, Nakaya Y, Matsuoka S, Kuroda Y. Effect of acidosis on $\mathrm{Ca}^{2+}$-activated $\mathrm{K}^{+}$channels in cultured porcine coronary artery smooth muscle cells. Pflügers Arch 1998;436:509-514.

45. Hensley K, Robinson KA, Gabbita SP, Salsman S, Floyd RA. Reactive oxygen species, cell signaling, and cell injury. Free Radic Biol Med 2000;28:1456-1462. [PubMed: 10927169]

46. Hercule HC, Salanova B, Essin K, Honeck H, Falck JR, Sausbier M, Ruth P, Schunck WH, Luft FC, Gollasch M. The vasodilator 17,18-epoxyeicosatetraenoic acid targets the pore-forming BK $\alpha$ channel subunit in rodents. Exp Physiol 2007;92:1067-1076. [PubMed: 17675416]

47. Horrigan FT, Aldrich RW. Coupling between voltage sensor activation, $\mathrm{Ca}^{2+}$ binding and channel opening in large conductance (BK) potassium channels. J Gen Physiol 2002;120:267-305. [PubMed: 12198087]

48. Horrigan FT, Heinemann SH, Hoshi T. Heme regulates allosteric activation of the Slo1 BK channel. J Gen Physiol 2005;126:7-21. [PubMed: 15955873]

49. Hoshi T, Heinemann S. Regulation of cell function by methionine oxidation and reduction. J Physiol 2001;531:1-11. [PubMed: 11179387]

50. Hou S, Reynolds MF, Horrigan FT, Heinemann SH, Hoshi T. Reversible binding of heme to proteins in cellular signal transduction. Acc Chem Res 2006;39:918-924. [PubMed: 17176030]

51. Hou S, Xu R, Heinemann SH, Hoshi T. Reciprocal regulation of the $\mathrm{Ca}^{2+}$ and $\mathrm{H}^{+}$sensitivity in the SLO1 BK channel conferred by the RCK1 domain. Nat Struct Mol Biol 2008;15:403-410. [PubMed: 18345016]

52. Hou S, Xu R, Heinemann SH, Hoshi T. The RCK1 high-affinity $\mathrm{Ca}^{2+}$ sensor confers carbon monoxide sensitivity to Slo1 BK channels. Proc Natl Acad Sci U S A 2008;105:4039-4043. [PubMed: 18316727]

53. Irani K. Oxidant signaling in vascular cell growth, death, and survival: a review of the roles of reactive oxygen species in smooth muscle and endothelial cell mitogenic and apoptotic signaling. Circ Res 2000;87:179-183. [PubMed: 10926866]

54. Jaggar JH, Leffler CW, Cheranov SY, Tcheranova D, ES, Cheng X. Carbon monoxide dilates cerebral arterioles by enhancing the coupling of $\mathrm{Ca}^{2+}$ sparks to $\mathrm{Ca}^{2+}$-activated $\mathrm{K}^{+}$channels. Circ Res 2002;91:610-617. [PubMed: 12364389] 
55. Jaggar JH, Li A, Parfenova H, Liu J, Umstot ES, Dopico AM, Leffler CW. Heme is a carbon monoxide receptor for large-conductance $\mathrm{Ca}^{2+}$-activated $\mathrm{K}^{+}$channels. Circ Res 2005;97:805-812. [PubMed: 16166559]

56. Jiang Y, Lee A, Chen J, Cadene M, Chait BT, MacKinnon R. Crystal structure and mechanism of a calcium-gated potassium channel. Nature 2002;417:515-522. [PubMed: 12037559]

57. Jiang Y, Pico A, Cadene M, Chait BT, MacKinnon R. Structure of the RCK domain from the $E$. coli $\mathrm{K}^{+}$channel and demonstration of its presence in the human BK channel. Neuron 2001;29:593-601. [PubMed: 11301020]

58. Johnson TR, Mann BE, Clark JE, Foresti R, Green CJ, Motterlini R. Metal carbonyls: a new class of pharmaceuticals? Angew Chem Int Ed Engl 2003;42:3722-3729. [PubMed: 12923835]

59. Kamp F, Guo W, Souto R, Pilch PF, Corkey BE, Hamilton JA. Rapid flip-flop of oleic acid across the plasma membrane of adipocytes. J Biol Chem 2003;278:7988-7995. [PubMed: 12499383]

60. Kassmann M, Hansel A, Leipold E, Birkenbeil J, Lu SQ, Hoshi T, Heinemann SH. Oxidation of multiple methionine residues impairs rapid sodium channel inactivation. Pflügers Arch 2008;456:1085-1095.

61. Kim HP, Ryter SW, Choi AM. CO as a cellular signaling molecule. Annu Rev Pharmacol Toxicol 2006;46:411-449. [PubMed: 16402911]

62. King JT, Lovell PV, Rishniw M, Kotlikoff MI, Zeeman ML, McCobb DP. $\beta 2$ and $\beta 4$ subunits of BK channels confer differential sensitivity to acute modulation by steroid hormones. $\mathbf{J}$ Neurophysiol 2006;95:2878-2888. [PubMed: 16436475]

63. Kirber MT, Ordway RW, Clapp LH, Walsh JV Jr, Singer JJ. Both membrane stretch and fatty acids directly activate large conductance $\mathrm{Ca}^{2+}$-activated $\mathrm{K}^{+}$channels in vascular smooth muscle cells. FEBS Lett 1992;297:24-28. [PubMed: 1551431]

64. Kitazawa T, Hamada E, Kitazawa K, Gaznabi AK. Non-genomic mechanism of $17 \beta$-oestradiolinduced inhibition of contraction in mammalian vascular smooth muscle. J Physiol 1997;499:497511. [PubMed: 9080377]

65. Knaus HG, Eberhart A, Koch RO, Munujos P, Schmalhofer WA, Warmke JW, Kaczorowski GJ, Garcia ML. Characterization of tissue-expressed $\alpha$ subunits of the high conductance $\mathrm{Ca}^{2+}$ activated $\mathrm{K}^{+}$channel. J Biol Chem 1995;270:22434-22439. [PubMed: 7673230]

66. Knaus HG, Folander K, Garcia-Calvo M, Garcia ML, Kaczorowski GJ, Smith M, Swanson R. Primary sequence and immunological characterization of $\beta$-subunit of high conductance $\mathrm{Ca}^{2+}$ activated $\mathrm{K}^{+}$channel from smooth muscle. J Biol Chem 1994;269:17274-17278. [PubMed: 8006036]

67. Kundu P, Alioua A, Stefani E, Toro L. Regulation of mouse Slo gene expression: multiple promoters, transcription start sites, and genomic action of estrogen. J Biol Chem 2007;282:2747827492. [PubMed: 17635926]

68. Lang RJ, Harvey JR. Thiol reagents and nitric oxide modulate the gating of $\mathrm{BK}_{\mathrm{Ca}}$ channels from the guinea-pig taenia caeci. Clin Exp Pharmacol Physiol 2002;29:944-949. [PubMed: 12207576]

69. Lang RJ, Harvey JR, McPhee GJ, Klemm MF. Nitric oxide and thiol reagent modulation of $\mathrm{Ca}^{2+}$ activated $\mathrm{K}^{+}\left(\mathrm{BK}_{\mathrm{Ca}}\right)$ channels in myocytes of the guinea-pig taenia caeci. J Physiol 2000;525:363-376. [PubMed: 10835040]

70. Lin H, McGrath JJ. Vasodilating effects of carbon monoxide. Drug Chem Toxicol 1988;11:371385. [PubMed: 3243186]

71. Lipton P. Ischemic cell death in brain neurons. Physiol Rev 1999;79:1431-1568. [PubMed: 10508238]

72. Liu Y, Terata K, Chai Q, Li H, Kleinman LH, Gutterman DD. Peroxynitrite inhibits $\mathrm{Ca}^{2+}$-activated $\mathrm{K}^{+}$channel activity in smooth muscle of human coronary arterioles. Circ Res 2002;91:1070-1076. [PubMed: 12456494]

73. Long SB, Campbell EB, Mackinnon R. Voltage sensor of Kv1.2: structural basis of electromechanical coupling. Science 2005;309:903-908. [PubMed: 16002579]

74. Long SB, Tao X, Campbell EB, MacKinnon R. Atomic structure of a voltage-dependent $\mathrm{K}^{+}$ channel in a lipid membrane-like environment. Nature 2007;450:376-382. [PubMed: 18004376]

75. Lovell PV, King JT, McCobb DP. Acute modulation of adrenal chromaffin cell BK channel gating and cell excitability by glucocorticoids. J Neurophysiol 2004;91:561-570. [PubMed: 12904339] 
76. Lu R, Alioua A, Kumar Y, Eghbali M, Stefani E, Toro L. MaxiK channel partners: physiological impact. J Physiol 2006;570:65-72. [PubMed: 16239267]

77. Lu T, He T, Katusic ZS, Lee HC. Molecular mechanisms mediating inhibition of human large conductance $\mathrm{Ca}^{2+}$-activated $\mathrm{K}^{+}$channels by high glucose. Circ Res 2006;99:607-616. [PubMed: 16931797]

78. Magleby KL. Gating mechanism of BK (Slo1) channels: so near, yet so far. J Gen Physiol 2003;121:81-96. [PubMed: 12566537]

79. Maines MD. The heme oxygenase system: a regulator of second messenger gases. Annu Rev Pharmacol Toxicol 1997;37:517-554. [PubMed: 9131263]

80. Maingret F, Patel AJ, Lesage F, Lazdunski M, Honore E. Mechano- or acid stimulation, two interactive modes of activation of the TREK-1 potassium channel. J Biol Chem 1999;274:2669126696. [PubMed: 10480871]

81. Matalon S, Hardiman KM, Jain L, Eaton DC, Kotlikoff M, Eu JP, Sun J, Meissner G, Stamler JS. Regulation of ion channel structure and function by reactive oxygen-nitrogen species. Am J Physiol Lung Cell Mol Physiol 2003;285:L1184-1189. [PubMed: 14604848]

82. McCartney CE, McClafferty H, Huibant JM, Rowan EG, Shipston MJ, Rowe IC. A cysteine-rich motif confers hypoxia sensitivity to mammalian large conductance voltage- and $\mathrm{Ca}^{2+}$-activated $\mathrm{K}^{+}$ (BK) channel $\alpha$-subunits. Proc Natl Acad Sci U S A 2005;102:17870-17876. [PubMed: 16306267]

83. McLaughlin S, Murray D. Plasma membrane phosphoinositide organization by protein electrostatics. Nature 2005;438:605-611. [PubMed: 16319880]

84. Meera P, Wallner M, Toro L. A neuronal $\beta$ subunit (KCNMB4) makes the large conductance, voltage- and $\mathrm{Ca}^{2+}$-activated $\mathrm{K}^{+}$channel resistant to charybdotoxin and iberiotoxin. Proc Natl Acad Sci U S A 2000;97:5562-5567. [PubMed: 10792058]

85. Moczydlowski E, Alvarez O, Vergara C, Latorre R. Effect of phospholipid surface charge on the conductance and gating of a $\mathrm{Ca}^{2+}$-activated $\mathrm{K}^{+}$channel in planar lipid bilayers. J Membr Biol 1985;83:273-282. [PubMed: 2582128]

86. Nadal A, Diaz M, Valverde MA. The estrogen trinity: membrane, cytosolic, and nuclear effects. News Physiol Sci 2001;16:251-255. [PubMed: 11719599]

87. Nara M, Dhulipala PD, Ji GJ, Kamasani UR, Wang YX, Matalon S, Kotlikoff MI. Guanylyl cyclase stimulatory coupling to $\mathrm{K}_{\mathrm{Ca}}$ channels. Am J Physiol Cell Physiol 2000;279:C1938-1945. [PubMed: 11078709]

88. Niu X, Qian X, Magleby KL. Linker-gating ring complex as passive spring and $\mathrm{Ca}^{2+}$-dependent machine for a voltage- and $\mathrm{Ca}^{2+}$-activated potassium channel. Neuron 2004;42:745-756. [PubMed: 15182715]

89. Orio P, Rojas P, Ferreira G, Latorre R. New disguises for an old channel: MaxiK channel $\beta$ subunits. News Physiol Sci 2002;17:156-161. [PubMed: 12136044]

90. Ortega-Saenz P, Pascual A, Gomez-Diaz R, Lopez-Barneo J. Acute oxygen sensing in heme oxygenase-2 null mice. J Gen Physiol 2006;128:405-411. [PubMed: 16966473]

91. Park JB, Kim HJ, Ryu PD, Moczydlowski E. Effect of phosphatidylserine on unitary conductance and $\mathrm{Ba}^{2+}$ block of the $\mathrm{BK} \mathrm{Ca}^{2+}$-activated $\mathrm{K}^{+}$channel: re-examination of the surface charge hypothesis. J Gen Physiol 2003;121:375-397. [PubMed: 12695485]

92. Park JK, Kim YC, Sim JH, Choi MY, Choi W, Hwang KK, Cho MC, Kim KW, Lim SW, Lee SJ. Regulation of membrane excitability by intracellular $\mathrm{pH}\left(\mathrm{pH}_{\mathrm{i}}\right)$ changers through $\mathrm{Ca}^{2+}$-activated $\mathrm{K}$ + current (BK channel) in single smooth muscle cells from rabbit basilar artery. Pflügers Arch 2007;454:307-319.

93. Piomelli D. Arachidonic acid in cell signaling. Curr Opin Cell Biol 1993;5:274-280. [PubMed: 7685181]

94. Qian X, Niu X, Magleby KL. Intra- and intersubunit cooperativity in activation of BK channels by $\mathrm{Ca}^{2+}$ J Gen Physiol 2006;128:389-404. [PubMed: 17001085]

95. Rajagopal A, Rao AU, Amigo J, Tian M, Upadhyay SK, Hall C, Uhm S, Mathew MK, Fleming MD, Paw BH, Krause M, Hamza I. Haem homeostasis is regulated by the conserved and concerted functions of HRG-1 proteins. Nature 2008;453:1127-1131. [PubMed: 18418376] 
96. Roberts GP, Youn H, Kerby RL. CO-sensing mechanisms. Microbiol Mol Biol Rev 2004;68:453473. [PubMed: 15353565]

97. Roman RJ. P-450 metabolites of arachidonic acid in the control of cardiovascular function. Physiol Rev 2002;82:131-185. [PubMed: 11773611]

98. Salkoff L, Butler A, Ferreira G, Santi C, Wei A. High-conductance potassium channels of the SLO family. Nat Rev Neurosci 2006;7:921-931. [PubMed: 17115074]

99. Santarelli LC, Chen J, Heinemann SH, Hoshi T. The $\beta 1$ subunit enhances oxidative regulation of large-conductance calcium-activated $\mathrm{K}^{+}$channels. J Gen Physiol 2004;124:357-370. [PubMed: 15452197]

100. Santarelli LC, Wassef R, Heinemann SH, Hoshi T. Three methionine residues located within the regulator of conductance for $\mathrm{K}^{+}(\mathrm{RCK})$ domains confer oxidative sensitivity to largeconductance $\mathrm{Ca}^{2+}$-activated $\mathrm{K}^{+}$channels. J Physiol 2006;571:329-348. [PubMed: 16396928]

101. Sausbier M, Arntz C, Bucurenciu I, Zhao H, Zhou XB, Sausbier U, Feil S, Kamm S, Essin K, Sailer CA, Abdullah U, Krippeit-Drews P, Feil R, Hofmann F, Knaus HG, Kenyon C, Shipston MJ, Storm JF, Neuhuber W, Korth M, Schubert R, Gollasch M, Ruth P. Elevated blood pressure linked to primary hyperaldosteronism and impaired vasodilation in BK channel-deficient mice. Circulation 2005;112:60-68. [PubMed: 15867178]

102. Schreiber M, Salkoff L. A novel calcium-sensing domain in the BK channel. Biophys J 1997;73:1355-1363. [PubMed: 9284303]

103. Schubert R, Nelson MT. Protein kinases: tuners of the $\mathrm{BK}_{\mathrm{Ca}}$ channel in smooth muscle. Trends Pharmacol Sci 2001;22:505-512. [PubMed: 11583807]

104. Shayeghi M, Latunde-Dada GO, Oakhill JS, Laftah AH, Takeuchi K, Halliday N, Khan Y, Warley A, McCann FE, Hider RC, Frazer DM, Anderson GJ, Vulpe CD, Simpson RJ, McKie AT. Identification of an intestinal heme transporter. Cell 2005;122:789-801. [PubMed: 16143108]

105. Soom M, Gessner G, Heuer H, Hoshi T, Heinemann SH. A mutually exclusive alternative exon of slo1 codes for a neuronal BK channel with altered function. Channels (Austin) 2008;2:278-282. [PubMed: 18719396]

106. Soto MA, Gonzalez C, Lissi E, Vergara C, Latorre R. $\mathrm{Ca}^{2+}$-activated $\mathrm{K}^{+}$channel inhibition by reactive oxygen species. Am J Physiol Cell Physiol 2002;282:C461-471. [PubMed: 11832330]

107. Stadtman ER. Protein oxidation and aging. Free Radic Res 2006;40:1250-1258. [PubMed: 17090414]

108. Starkus JG, Varga Z, Schonherr R, Heinemann SH. Mechanisms of the inhibition of Shaker potassium channels by protons. Pflügers Arch 2003;447:44-54.

109. Suh BC, Hille B. PIP2 is a necessary cofactor for ion channel function: how and why? Annu Rev Biophys 2008;37:175-195. [PubMed: 18573078]

110. Sun X, Zhou D, Zhang P, Moczydlowski EG, Haddad GG. $\beta$-subunit-dependent modulation of hSlo BK current by arachidonic acid. J Neurophysiol 2007;97:62-69. [PubMed: 17021030]

111. Syntichaki P, Tavernarakis N. The biochemistry of neuronal necrosis: rogue biology? Nat Rev Neurosci 2003;4:672-684. [PubMed: 12894242]

112. Tang XD, Daggett H, Hanner M, Garcia ML, McManus OB, Brot N, Weissbach H, Heinemann $\mathrm{SH}$, Hoshi T. Oxidative regulation of large conductance calcium-activated potassium channels. J Gen Physiol 2001;117:253-274. [PubMed: 11222629]

113. Tang XD, Garcia ML, Heinemann SH, Hoshi T. Reactive oxygen species impair Slo1 BK channel function by altering cysteine-mediated calcium sensing. Nat Struct Mol Biol 2004;11:171-178. [PubMed: 14745441]

114. Tang XD, Xu R, Reynolds MF, Garcia ML, Heinemann SH, Hoshi T. Haem can bind to and inhibit mammalian calcium-dependent Slo1 BK channels. Nature 2003;425:531-535. [PubMed: 14523450]

115. Tseng-Crank J, Foster CD, Krause JD, Mertz R, Godinot N, DiChiara TJ, Reinhart PH. Cloning, expression, and distribution of functionally distinct $\mathrm{Ca}^{2+}$-activated $\mathrm{K}^{+}$channel isoforms from human brain. Neuron 1994;13:1315-1330. [PubMed: 7993625] 
116. Vaithianathan T, Bukiya A, Liu J, Liu P, Asuncion-Chin M, Fan Z, Dopico A. Direct regulation of BK channels by phosphatidylinositol 4,5-bisphosphate as a novel signaling pathway. J Gen Physiol 2008;132:13-28. [PubMed: 18562499]

117. Valverde MA, Rojas P, Amigo J, Cosmelli D, Orio P, Bahamonde MI, Mann GE, Vergara C, Latorre R. Acute activation of Maxi-K channels (hSlo) by estradiol binding to the $\beta$ subunit. Science 1999;285:1929-1931. [PubMed: 10489376]

118. Vergara C, Latorre R, Marrion NV, Adelman JP. Calcium-activated potassium channels. Curr Opin Neurobiol 1998;8:321-329. [PubMed: 9687354]

119. Wallner M, Meera P, Toro L. Molecular basis of fast inactivation in voltage and $\mathrm{Ca}^{2+}$-activated $\mathrm{K}$ + channels: a transmembrane $\beta$-subunit homolog. Proc Natl Acad Sci U S A 1999;96:4137-4142. [PubMed: 10097176]

120. Wang $\mathrm{R}, \mathrm{Wu} \mathrm{L}$. The chemical modification of $\mathrm{K}_{\mathrm{Ca}}$ channels by carbon monoxide in vascular smooth muscle cells. J Biol Chem 1997;272:8222-8226. [PubMed: 9079640]

121. Wang ZW, Nara M, Wang YX, Kotlikoff MI. Redox regulation of large conductance $\mathrm{Ca}^{2+}$ activated $\mathrm{K}^{+}$channels in smooth muscle cells. J Gen Physiol 1997;110:35-44. [PubMed: 9234169]

122. White RE, Kryman JP, El-Mowafy AM, Han G, Carrier GO. cAMP-dependent vasodilators cross-activate the cGMP-dependent protein kinase to stimulate $\mathrm{BK}_{\mathrm{Ca}}$ channel activity in coronary artery smooth muscle cells. Circ Res 2000;86:897-905. [PubMed: 10785513]

123. Williams SE, Brazier SP, Baban N, Telezhkin V, Muller CT, Riccardi D, Kemp PJ. A structural motif in the C-terminal tail of slo1 confers carbon monoxide sensitivity to human $\mathrm{BK}_{\mathrm{Ca}}$ channels. Pflügers Arch 2008;456:561-572.

124. Williams SE, Wootton P, Mason HS, Bould J, Iles DE, Riccardi D, Peers C, Kemp PJ. Hemoxygenase- 2 is an oxygen sensor for a calcium-sensitive potassium channel. Science 2004;306:2093-2097. [PubMed: 15528406]

125. Wood LS, Vogeli G. Mutations and deletions within the S8-S9 interdomain region abolish complementation of $\mathrm{N}$ - and C-terminal domains of $\mathrm{Ca}^{2+}$-activated $\mathrm{K}^{+}(\mathrm{BK})$ channels. Biochem Biophys Res Commun 1997;240:623-628. [PubMed: 9398615]

126. Wu L, Cao K, Lu Y, Wang R. Different mechanisms underlying the stimulation of $\mathrm{K}_{\mathrm{Ca}}$ channels by nitric oxide and carbon monoxide. J Clin Invest 2002;110:691-700. [PubMed: 12208870]

127. Wu SN, Li HF, Chiang HT. Actions of epoxyeicosatrienoic acid on large-conductance $\mathrm{Ca}^{2+}$ activated $\mathrm{K}^{+}$channels in pituitary GH3 cells. Biochem Pharmacol 2000;60:251-262. [PubMed: 10825470]

128. Xi Q, Cheranov SY, Jaggar JH. Mitochondria-derived reactive oxygen species dilate cerebral arteries by activating $\mathrm{Ca}^{2+}$ sparks. Circ Res 2005;97:354-362. [PubMed: 16020754]

129. Xi Q, Tcheranova D, Parfenova H, Horowitz B, Leffler CW, Jaggar JH. Carbon monoxide activates $\mathrm{K}_{\mathrm{Ca}}$ channels in newborn arteriole smooth muscle cells by increasing apparent $\mathrm{Ca}^{2+}$ sensitivity of $\alpha$-subunits. Am J Physiol Heart Circ Physiol 2004;286:H610-618. [PubMed: 14563665]

130. Xia XM, Zeng X, Lingle CJ. Multiple regulatory sites in large-conductance calcium-activated potassium channels. Nature 2002;418:880-884. [PubMed: 12192411]

131. Xie J, McCobb DP. Control of alternative splicing of potassium channels by stress hormones. Science 1998;280:443-446. [PubMed: 9545224]

132. Xu W, Liu Y, Wang S, McDonald T, Van Eyk JE, Sidor A, O'Rourke B. Cytoprotective role of $\mathrm{Ca}^{2+}$ - activated $\mathrm{K}^{+}$channels in the cardiac inner mitochondrial membrane. Science 2002;298:1029-1033. [PubMed: 12411707]

133. Xu Y, Ramu Y, Lu Z. Removal of phospho-head groups of membrane lipids immobilizes voltage sensors of $\mathrm{K}^{+}$channels. Nature 2008;451:826-829. [PubMed: 18273018]

134. Yao H, Haddad GG. Calcium and $\mathrm{pH}$ homeostasis in neurons during hypoxia and ischemia. Cell Calcium 2004;36:247-255. [PubMed: 15261480]

135. Yusifov T, Savalli N, Gandhi CS, Ottolia M, Olcese R. The RCK2 domain of the human $B K_{C a}$ channel is a calcium sensor. Proc Natl Acad Sci U S A 2008;105:376-381. [PubMed: 18162557]

136. Zagorac D, Yamaura K, Zhang C, Roman RJ, Harder DR. The effect of superoxide anion on autoregulation of cerebral blood flow. Stroke 2005;36:2589-2594. [PubMed: 16293785] 
137. Zhang G, Xu R, Heinemann SH, Hoshi T. Cysteine oxidation and rundown of large-conductance $\mathrm{Ca}^{2+}$-dependent $\mathrm{K}^{+}$channels. Biochem Biophys Res Commun 2006;342:1389-1395. [PubMed: 16516848]

138. Zhang H, Craciun LC, Mirshahi T, Rohacs T, Lopes CM, Jin T, Logothetis DE. PIP2 activates KCNQ channels, and its hydrolysis underlies receptor-mediated inhibition of M currents. Neuron 2003;37:963-975. [PubMed: 12670425] 


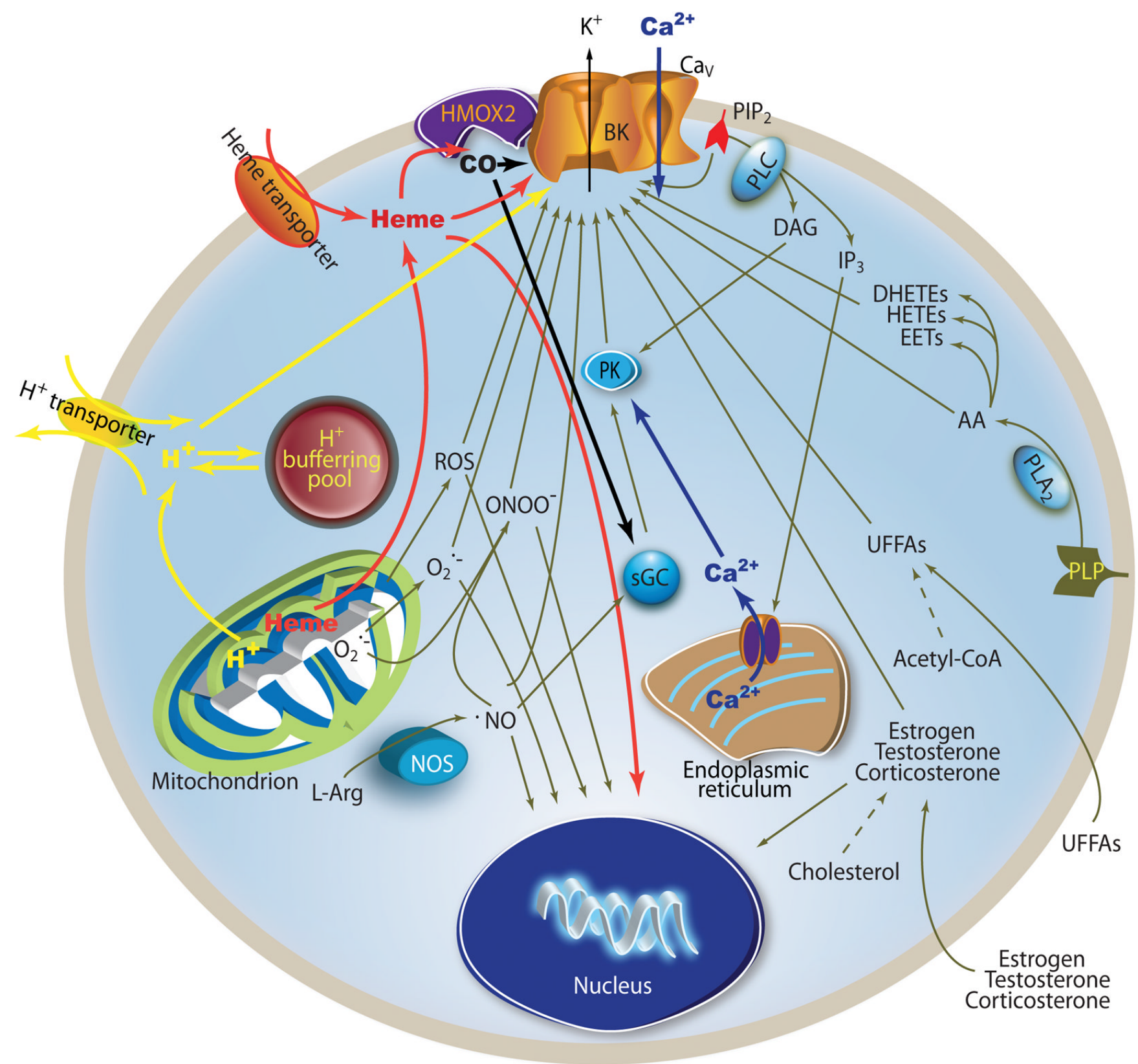

Figure 1.

Multiple intracellular signaling cascades modulate $\mathrm{BK}_{\mathrm{Ca}}$ channels. PLP (phospholipids) UFFAs (unsaturated free fatty acids) NOS (nitric oxide synthase), PK (protein kinase), sGC (soluble guanylyl cyclase), PLA 2 (Phospholipase $\mathrm{A}_{2}$ ), PLC (Phospholipase C), IP 3 (Inositol triphosphate), DAG (diglyceride), L-Arg (L-arginine) 


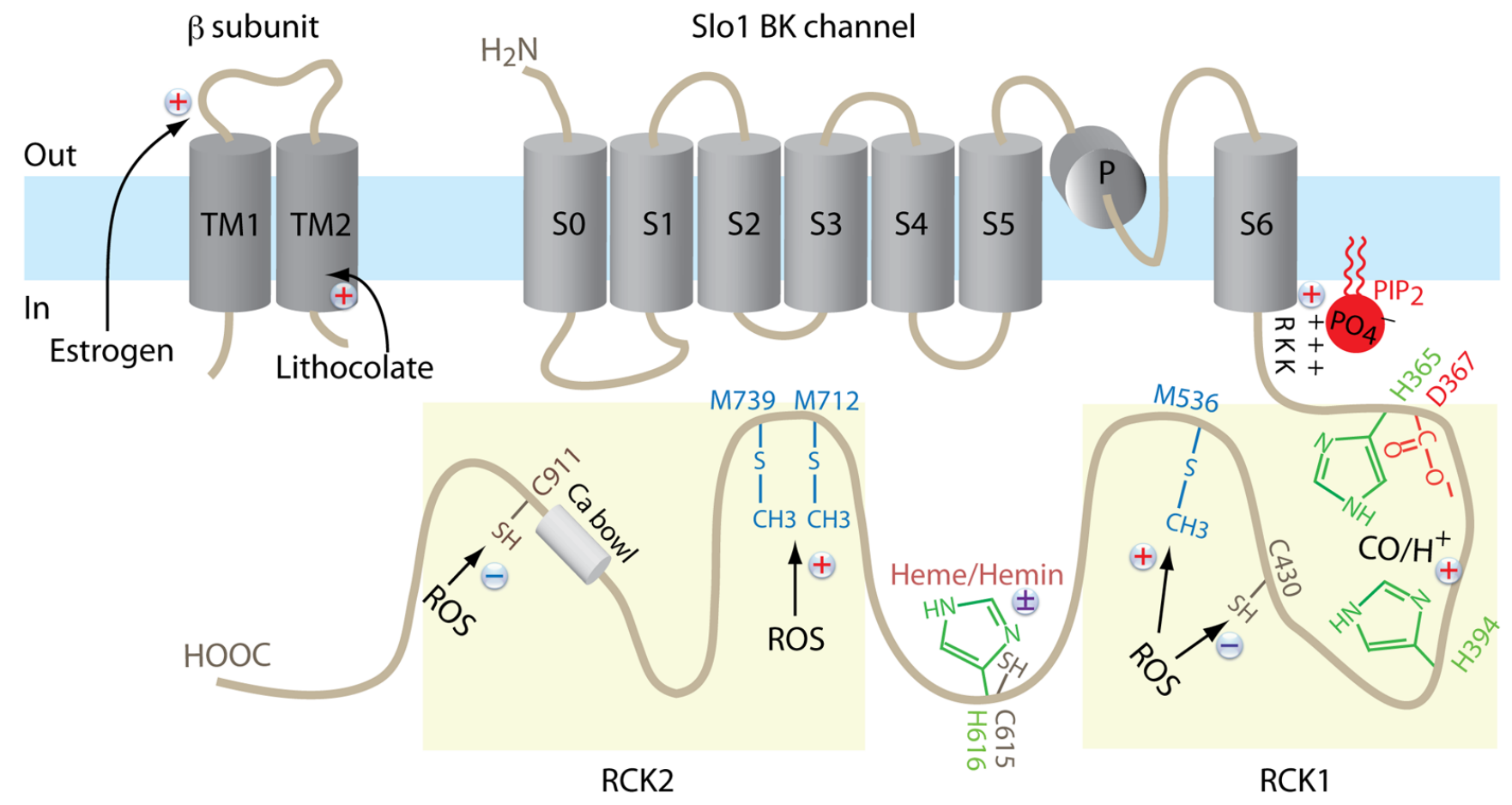

Figure 2.

The schematic diagram shows the key amino acid residues involved in modulation of $\mathrm{BK}_{\mathrm{Ca}}$ channel by select intracellular messengers including $\mathrm{H}^{+}$, heme/hemin, $\mathrm{CO}, \mathrm{ROS}$, and $\mathrm{PIP}_{2}$. Stimulatory modulators are indicated by “+”, inhibitory modulators are indicated "-_and mixed-effect modulators are indicated by " \pm ”. The residue numbers are according to NP 002238. 